\title{
Investigation of Heavy Metals Level in selected Boreholes around the Vicinity of some Cemeteries in Benin City, Nigeria
}

\author{
IBHADODE, CAE; *ILABOYA, IR
}

\author{
Department of Civil Engineering, Faculty of Engineering, University of Benin, P.M.B 1154, Benin City, Edo State, Nigeria \\ *Corresponding Author Email: rudolph.ilaboya@uniben.edu
}

\begin{abstract}
Groundwater pollution by heavy metals such as lead, copper, nickel and iron is one of the major environmental issues of concern which has developed into a widely studied area. In this study, attempt was made to investigate the level of heavy metals in selected boreholes around the vicinity of cemeteries in Benin City. Seventy-two (72) samples of groundwater were taken from boreholes in 9 stations around the three cemeteries in Benin City on monthly basis. The samples were analysed for 7 heavy metals, in accordance with standard procedures. The heavy metals include; Zinc, Lead Iron, Copper, Cadmium, Nickel and Mercury. From the results of the study, a variation in the mean concentration of zinc was observed. The mean concentration of zinc in site 1 was $0.450 \mathrm{mg} / 1$, for site 2 , it was $0.140 \mathrm{mg} / 1$ and for site 3 , it was $1.0533 \mathrm{mg} / \mathrm{l}$. For iron, mean concentration was $0.072 \mathrm{mg} / \mathrm{l}$ in site 1 . For site 2 , mean concentration of iron was $2.140 \mathrm{mg} / \mathrm{l}$ and for site 3 , mean concentration of iron was $0.560 \mathrm{mg} / \mathrm{l}$. It was further revealed based on the results that mean value of heavy metals in groundwater around cemeteries in Benin City were generally lower during dry season compared to wet season. In addition, result of computed pollution index (Pi) revealed that the heavy metal with the highest potential to pollute groundwater is Cadmium, with $\mathrm{Pi}$ of 0.5333 and 0.400 representing dry season and wet season respectively.
\end{abstract}

\section{DOI: https://dx.doi.org/10.4314/jasem.v25i5.24}

Copyright: Copyright $\odot 2021$ Ibhadode and Ilaboya. This is an open access article distributed under the Creative Commons Attribution License (CCL), which permits unrestricted use, distribution, and reproduction in any medium, provided the original work is properly cited.

Dates: Received: 20 March 2021; Revised: 27 April 2021; Accepted: 07 May 2021

Keyword: Heavy metals, Ground water, Copper, Cadmium, Iron, Nickel and Zinc

Water is a critical resource in the sustenance of all forms of life. It has also been described as a universal solvent, which is highly essential in all sectors of the economy, including agriculture, domestic use, industrial sector, and in sewage disposal. This allimportant fluid constitutes $64 \%$ of the human body (Environment Agency 2004). Water fit for human consumption is called potable water (Kudesia and Kudesia 2008). Economic development, increase in human population, and extensive agricultural activities exert heavy pressure on water, making it relatively scarce. In areas where surface water like rivers, springs and lakes that produce fresh waters are lacking, groundwater becomes the major source (Kupchella and Hylan 1992). Groundwater is sourced from geologic zones in the ground called aquifers. Aquifers are a body of rock or regolith, sufficiently permeable to conduct economically significant quantities of groundwater to springs and wells (Skinner and Porter 1995). Groundwater is simply water located beneath the ground surface in soil pore spaces and in the fractures of rock formations (Adeyeye and Abulude, 2004). It is about $20 \%$ of the world's fresh water supply and it is about $0.61 \%$ of the entire world's water which includes the oceans and permanent ice (Asadi et al., 2007). The real source of groundwater is the infiltration of precipitation into the ground, following rainfall (Skinner and Porter 1995). So, aquifers are recharged by rainfall. Rainfall is known to facilitate the mobilization of contaminants into groundwater during percolation. Groundwater can be contaminated from a number of point-sources such as leaks of hazardous wastes from underground storage tanks and leachates from landfills. It can also be contaminated from diffuse source such as seepage of organic and inorganic compounds from agricultural fields. Once contaminated, groundwater is almost impossible to cleanse unlike surface water that undergoes selfpurification, over time and space (Chakrabotty et al., 2004; Cave et al., 2004). Environment Agency (2004) has said that groundwater has been identified as the most potentially vulnerable receptor of pollutants from cemeteries. According to Ucisik and Rushbrook (1998), decayed corpses in cemeteries may cause groundwater contamination. Rim-Rukeh (2009) and Kudesia and Kudesia (2008) have identified toxic heavy metals to include Cadmium, Lead and Mercury. Non-toxic heavy metals are Manganese, Cobalt, Iron Copper and Zinc. All such parameters at various concentrations are potential pollutants to groundwater. Where a cemetery is built on a soil of low porosity and low permeability underlain by a saturated geologic zone above $50 \mathrm{~m}$ thick, percolated decomposition products from it can be prevented from reaching the groundwater beneath (Environment Agency, 2004). This zone inhibits seepage of decomposition products into groundwater. The processes involved in this attenuation of contaminants include filtration, adsorption biodegradation and chemical oxidation (Pedley and Guy, 1996). In a study on Groundwater 
Contamination from Cemeteries in Portugal, Rodrigues and Pacheco (2003) found out that cemeteries may contribute to groundwater contamination only on the condition that animal remains are buried within $250 \mathrm{~m}$ of the cemetery. They also said that soil geology and aquifer types are key variables in groundwater contamination from cemeteries. Kiptom and Ndambuki (2012) found out in Langas district in Kenya that groundwater abstracted closer than $48 \mathrm{~m}$ to pit latrines were contaminated. The objective of the investigation of heavy metals level in selected boreholes around the vicinity of cemeteries in Benin City, Nigeria was to evaluate the damages done to groundwater quality as a result of human decomposition and also to monitor the compliance of residents to the environmental laws regulating the siting of boreholes around the vicinity of cemetery

\section{MATERIALS AND METHODS}

Benin City, the capital of Edo State, Nigeria which is the study area is located in the rain forest zone, with geographical coordinates of latitudes $6^{\circ} 17^{1} \mathrm{~N}, 6^{\circ} 26^{1} \mathrm{~N}$ and longitudes $5^{\circ} 35^{1} \mathrm{E}$, and annual mean temperature of $27.5^{\circ} \mathrm{C}$ (Ikhuoria, 1987). It has two main seasons, wet and dry; from April to November and November to April respectively, with an annual mean rainfall of about 2095mm (Ikhile and Olorode 2011). In matters of hydrogeology, Benin City lies on the Benin Formation, with an aquifer of mean depth of $136 \mathrm{~m}$ (Ikhile and Olorode 2011). Schools, hospitals, markets and cemeteries are among the social services provided in the City. Figure 1 shows the digitized map of the study area.

Location of sample stations: Three sample stations were located at each of the three cemeteries in Benin
City. At each cemetery, two sample stations were located at different distances within $100 \mathrm{~m}$ radius of the cemetery and a third, outside the $100 \mathrm{~m}$ radius, which served as the control. The coordinate of the sample stations were obtained by means of the Global Positioning System (GPS) and distances were determined by scaling from the plotting of the points against their cemeteries.

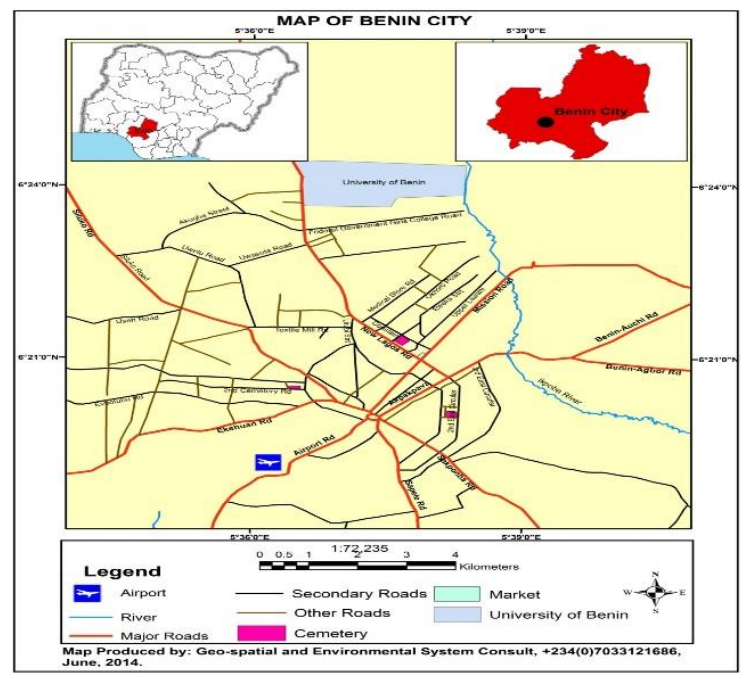

Fig 1: Map of Benin City showing the cemeterie

Groundwater samples were collected from boreholes in each of the 9 sample stations for 4 months in dry season (Nov and Dec 2012; Jan and Feb 2019). The sampling was replicated in wet season (May, June, July and Sept 2019). Means of the 4 readings in each station, at each cemetery, in each season were taken. Details of the sampling stations, their coordinates and distances from the cemeteries are presented in Table 1

Table 1: Description of sampling locations

\begin{tabular}{lllll}
\hline $\begin{array}{l}\text { Station } \\
\text { Description }\end{array}$ & Stn. & \multicolumn{2}{l}{ Coordinates $(\mathbf{m})$} & $\begin{array}{l}\text { Distance } \\
(\mathbf{m})\end{array}$ \\
\cline { 3 - 4 } $\begin{array}{l}\text { First Cemetery } \\
\text { (site 1) }\end{array}$ & 1 & 257986 & 356522 & 8 \\
& 2 & 258241 & 356664 & 94 \\
Second & 3 & 258380 & 356766 & 240 \\
Cemetery & 1 & 258943 & 353523 & 5 \\
(site 2) & 2 & 259010 & 353435 & 40 \\
Third Cemetery & 3 & 259222 & 353394 & 250 \\
(site 3) & 1 & 260664 & 355555 & 45 \\
& 2 & 260698 & 355499 & 140 \\
& 3 & 260990 & 355155 & 570 \\
\hline
\end{tabular}

Analysis of samples: The water samples were analysed in triplicates to obtain the mean value and standard deviation of each water quality test parameters. The samples were labelled properly and stored in air tight, clean and dried plastic containers. At every point of collection, the clean, dried plastic containers were rinsed two to three times with the borehole water to be sampled before collection. The collected samples were then kept in a refrigerator before analysis. Heavy metals present in the water samples was determined using Atomic absorption spectrometer (UNICAM
969). The source of radiation is a hollow lamp, which contains a cathode constructed of the same metals being analysed. This emits the wavelength characteristic of the metal and a different lamp is required for each metal. The light from the lamp is directed through a flame and onto monochromator, which selects the preferred analytical wavelength. The light monochromator is detected by a photomultiplier tube and converted to an electrical signal. 


\begin{tabular}{|c|c|c|c|c|c|c|c|c|c|c|c|c|c|c|}
\hline \multirow[t]{2}{*}{$\begin{array}{l}\text { S/ } \\
\text { No }\end{array}$} & \multirow[t]{2}{*}{ Parameter } & \multirow[t]{2}{*}{$\begin{array}{l}\text { WHO Std. } \\
(\mathrm{mg} / \mathrm{L})\end{array}$} & \multicolumn{4}{|c|}{$\begin{array}{l}\text { Site } 1 \\
\text { New Benin Cemetery }\end{array}$} & \multicolumn{4}{|c|}{$\begin{array}{l}\text { Site } 2 \\
\text { Second East Circular Cemetery }\end{array}$} & \multicolumn{4}{|c|}{$\begin{array}{l}\text { Site } 3 \\
\text { Oliha Quarters Cemetery }\end{array}$} \\
\hline & & & Min & Max & Mean & Std dev. & Min & Max & Mean & Std dev. & Min & Max & Mean & Std dev. \\
\hline 1 & Zinc & 3.0 & 0.30 & 0.60 & 0.45 & 0.161 & 0.12 & 0.16 & 0.14 & 0.02 & 0.78 & 1.23 & 1.0533 & 0.240 \\
\hline 2 & Lead & 0.01 & 0.002 & 0.006 & 0.004 & 0.0020 & 0.0 & 0.0 & 0.0 & 0.0 & 0.0 & 0.0 & 0.0 & 0.0 \\
\hline 3 & Iron & 0.30 & 0.04 & 0.13 & 0.072 & 0.0058 & 1.27 & 3.19 & 2.14 & 0.973 & 0.38 & 0.79 & 0.56 & 0.2095 \\
\hline 4 & Copper & 1.0 & 0.012 & 0.035 & 0.0233 & 0.0115 & 0.003 & 0.013 & 0.0065 & 0.0056 & 0.01 & 0.03 & 0.02 & 0.010 \\
\hline 5 & Cadmium & 0.003 & 0.0 & 0.0 & 0.0 & 0.0 & 0.0 & 0.001 & 0.00067 & 0.00058 & 0.0 & 0.001 & 0.00067 & 0.00058 \\
\hline 6 & Nickel & 0.02 & 0.0 & 0.0 & 0.0 & 0.0 & 0.0 & 0.0 & 0.0 & 0.0 & 0.0 & 0.0 & 0.0 & 0.0 \\
\hline 7 & Mercury & 0.001 & 0,0 & 0.0 & 0.0 & 0.0 & 0.0 & 0.0 & 0.0 & 0.0 & 0.0 & 0.0 & 0.0 & 0.0 \\
\hline
\end{tabular}

Table 3: Chemical Characteristics of Groundwater around Cemeteries in Benin City (Wet Season)

\begin{tabular}{|c|c|c|c|c|c|c|c|c|c|c|c|c|c|c|}
\hline \multirow[t]{2}{*}{ S/No } & \multirow[t]{2}{*}{ Parameter } & \multirow[t]{2}{*}{$\begin{array}{l}\begin{array}{l}\text { WHO Std } \\
(\mathrm{mg} / \mathrm{L})\end{array} \\
\end{array}$} & \multicolumn{4}{|c|}{$\begin{array}{l}\text { Site } 1 \\
\text { New Benin Cemetery }\end{array}$} & \multicolumn{4}{|c|}{$\begin{array}{l}\text { Site } 2 \\
\text { Second East Circular Cemetery }\end{array}$} & \multicolumn{4}{|c|}{$\begin{array}{l}\text { Site } 3 \\
\text { Oliha Quarters Cemetery }\end{array}$} \\
\hline & & & Min & Max & Mean & Std dev. & Min & Max & Mean & Std dev. & Min & Max & Mean & Std dev. \\
\hline 1 & Zinc & 3.0 & 0.67 & 1.68 & 1.13 & 0.511 & 0.89 & 2.42 & 1.697 & 0.768 & 1.03 & 1.48 & 1.25 & 0.225 \\
\hline 2 & Lead & 0.01 & 0 & 0 & 0 & 0 & 0 & 0 & 0 & 0 & 0 & 0 & 0 & 0 \\
\hline 3 & Iron & 0.30 & 0.01 & 0.025 & 0.0187 & 0.0078 & 0.011 & 0.16 & 0.0687 & 0.080 & 0.01 & 0.020 & 0.0167 & 0.0058 \\
\hline 4 & Copper & 1.0 & 0.012 & 0.035 & 0.0233 & 0.0115 & 0.003 & 0.013 & 0.0097 & 0.0058 & 0.00 & 0.030 & 0.017 & 0.015 \\
\hline 5 & Cadmium & 0.003 & 0.001 & 0.0014 & 0.00117 & 0.0002 & 0.002 & 0.002 & 0.0018 & 0.0003 & 0.00 & 0.001 & 0.00067 & 0.00058 \\
\hline 6 & Nickel & 0.02 & 0.010 & 0.013 & 0.011 & 0.0017 & 0.001 & 0.002 & 0.00143 & 0.0005 & 0.0 & 0.002 & 0.00117 & 0.00104 \\
\hline 7 & Mercury & 0.001 & 0 & 0 & 0 & 0 & 0 & 0.0001 & 0.00003 & 0.00006 & 0 & 0 & 0 & 0 \\
\hline
\end{tabular}

The sample is aspirated in acetylene-air flame where the water is evaporated and the metal containing compounds are volatilized and dissociated into ground state atoms. The ground state atoms absorb the radiation from the hollow cathode lamp and are excited to higher energy levels, the concentration level of the parameter is displayed on the computer.

\section{RESULTS AND DISCUSSION}

Descriptive Statistics of the heavy metal composition of the samples are presented in Tables 2 and 3. World Health Organization (WHO) (2011) drinking water quality was used as the standard. Results have shown that the heavy metals analysed fell comfortably within the WHO permissible limits. .Parameters that recorded zero in dry season was Nickel and Mercury. In wet season, Lead only, recorded zero in all the stations. It showed lower values, compared to those obtained by Akpovita et al., (2011) in a similar work on borehole water around selected locations Benin City and Agbor respectively. Mercury had a mean \pm standard deviation of $0.00003 \pm 0.00006 \mathrm{mg} / \mathrm{l}$ in station 4 at Second Cemetery and remains the only station in which mercury was recorded in the entire study.
This was however the closest station to cemetery boundary in the study, with a distance of $5 \mathrm{~m}$ away from the cemetery. The trace of $\mathrm{Hg}$ in this station may be attributed to the porosity of the soil which allows leachate from human decomposition to infiltrate into the underlying aquifer. Toxic heavy metals such as zinc $(\mathrm{Zn})$, cadmium $(\mathrm{Cd})$, nickel $(\mathrm{Ni})$ and mercury $(\mathrm{Hg})$ exhibited increase in values from dry to wet season. Mean \pm standard deviation values of $\mathrm{Zn}$ in all the stations were $0.548 \pm 0.043 \mathrm{mg} / \mathrm{l}$ and $1.326 \pm 0.041 \mathrm{mg} / \mathrm{l}$ for dry and wet seasons respectively. Though the mean values of $\mathrm{Zn}$ were below the WHO standard, they were higher than the results obtained by Akpovita et al., (2011), from borehole water in Benin City and Agbor, Delta State, with a range of $0.10-0.12 \mathrm{mg} / \mathrm{l}$. Mean \pm standard deviation values of $\mathrm{Cd}$ for both dry and wet seasons were 0.0016 $\pm 0.0032 \mathrm{mg} / \mathrm{l}$ and $0.0012 \pm 0.0006 \mathrm{mg} / \mathrm{l}$ respectively. Cd values were however lower than ones obtained by Akpovita et al., (2011) in a similar work, with a range of $0.003-0.006 \mathrm{mg} / \mathrm{l}$. For $\mathrm{Ni}$, mean \pm standard deviation was zero during the dry season and $0.0045 \pm 0.005 \mathrm{mg} / \mathrm{l}$ in wet season. These values were lower than one reported by Akpovita et al., (2011). Lead exhibited a different pattern from other heavy metals, as it showed decrease in values from dry to wet season.

IBHADODE, CAE; ILABOYA, IR 
It recorded zero in all the stations except Third Cemetery with $0.004 \pm 0.002 \mathrm{mg} / \mathrm{l}$, in dry season. Lower values of $\mathrm{Pb}$ were obtained in the same similar work on groundwater in Benin City by Akpovita et al., (2011), with a range of $0.013-0.015 \mathrm{mg} / \mathrm{l}$. The low level of heavy metals in all the stations, especially in dry season, is attributed to the paucity of rainfall in dry season which discourages the percolation of potential contaminants into groundwater. In the process of downward descent, potential contaminants in groundwater are attenuated by the processes of filtration, adsorption and ion exchange (Okokoyo and Rim-Rukeh 2004). To better understand the pollution dynamics of boreholes around the vicinity of cemeteries, the water pollution index of the waters samples were calculated. Pollution index (Pi) is expressed as a function of the concentration of individual parameter as against the baseline standard (Akpoveta et al., 2011). It is normally expressed as:

$$
P_{i}=\left(\frac{C}{S}\right)
$$

Where; $\mathrm{Pi}$ is the pollution index, $\mathrm{C}$ is the concentration of the parameter (test result) and $\mathrm{S}$ is the standard for the parameter (WHO standard). The critical value of $\mathrm{Pi}$ is 1.0. All values greater than 1 shows significant level of pollution. Conversely, Pi values less than 1 indicates no pollution. The computed pollution indices is presented in Table 4.

Table 4 Mean of Parameters Tested and Pollution Indices

\begin{tabular}{llllll}
\hline Parameter & $\begin{array}{l}\text { WHO Std } \\
(\mathbf{S})(\mathbf{m g} / \mathbf{l})\end{array}$ & \multicolumn{2}{c}{$\begin{array}{c}\text { Test Result } \\
(\mathbf{C})(\mathbf{m g} / \mathbf{l})\end{array}$} & \multicolumn{2}{c}{$\begin{array}{c}\text { Pollution } \\
\text { Index (Pi) }\end{array}$} \\
\hline & & Dry Season & $\begin{array}{l}\text { Wet } \\
\text { Season }\end{array}$ & $\begin{array}{l}\text { Dry } \\
\text { Season }\end{array}$ & $\begin{array}{l}\text { Wet } \\
\text { Season }\end{array}$ \\
\hline Zinc & 3.00 & $0.548 \pm 0.428$ & $1.359 \pm 0.541$ & 0.1827 & 0.442 \\
Lead & 0.010 & $0.0 .0022 \pm 0.0001$ & 0.0000 & 0.220 & 0.000 \\
Cadmium & 0.003 & $0.0016 \pm 0.0032$ & $0.0012 \pm 0.006$ & 0.533 & 0.400 \\
Nickel & 0.020 & 0.0000 & $0.0045 \pm 0.005$ & 0.000 & 0.225 \\
Mercury & 0.001 & 0.0000 & $0.00001 \pm 0.000$ & 0.000 & 0.010 \\
Copper & 1.00 & $0.0162 \pm 0.0112$ & $0.0167 \pm 0.0014$ & 0.0162 & 0.0167 \\
Iron & 0.36 & $0.924 \pm 0.001$ & $0.0344 \pm 0.048$ & 0.1028 & 0.0964 \\
\hline
\end{tabular}

Results have shown that the pollution indices followed the pattern of test results between dry and wet seasons at the three cemeteries. Values of Pi in dry season were generally lower than wet season as revealed in Table 4. This is an indication that contamination by heavy metals of groundwater around cemeteries in Benin City is higher in wet season than in dry season The Pi of Mercury and Nickel was zero in dry season as well as Lead in wet season. The mean values of Iron (a nontoxic heavy metal) increased in dry season with 0.924 $\mathrm{mg} / \mathrm{l}$ over wet season with $0.034 \mathrm{mg} / \mathrm{l}$. Research has shown that the three toxic heavy metals that would contributed most to the groundwater contamination in descending order of $\mathrm{Pi}$, in dry season are; Cadmium, Lead and Zinc, with Pi of 0.5333, 0.220 and 0.182, respectively. Wet season values of $\mathrm{Pi}$ for all the stations were $0.442,0.400$ and 0.225 for Zinc Cadmium and Nickel respectively. Of all the heavy metals studied. Cadmium featured as the parameter with highest potential to contaminate groundwater.

Conclusion: Groundwater around cemeteries in Benin City is generally not at the risk of heavy metals pollution, as the test results have shown that they fall comfortably within the WHO permissible levels. Nevertheless, Human activities like smelting, production of paints and printing that generates traces of heavy metals that can further spike their concentration should be avoided in areas where groundwater is abstracted, to forestall possible contamination.

\section{REFERENCES}

Aderemi, AO; Oriakhi, AV; Adewumi, GA; Otitoloju AA (2011). Assessment of groundwater contamination by leachate near a municipal solid Waste landfill. Afr. J. Environ. Sci. Technol. 5 (11): 933-940

Adeyeye, EI; Abulude, FO (2004). Analytical assessment to some surface and groundwater resources in Ile-Ife Nigeria. J. Chem. Soc. Nig. 29 (1): $98-103$

Akpoveta, OV; Okoh, BE; Osakwe, SA (2011). Quality assessment of borehole water used in the vicinity of Benin, Edo State and Agbor, Delta State of Nigeria. Cur. Res. Chem. 3 (1): 62-69

American Public Health Association (APHA) (1998). Standard methods for the examination of water and wastewater; 20th edition, American Public Health Association, Washington DC., pp 1220

Asadi, SS; Vuppala, P; Reddy, MA (2007). Remote sensing and GIS techniques for evaluation of groundwater in Municipal Corporation of Hyderabad. India Inter. J. Environ. Res. Public Health. 4 (1): 45-52.

Atsegbua, L; Akpotaire, V; Dimowo, F (2010). Environmental Law in Nigeria: Theory and Practice. Ambik Press, Benin City. 1: 22-33 
Chakraborty, D; Sengupta, MM; Rahman, SA; Chowdhury, UK; Mukherjee, SC (2004). Groundwater arsenic contamination and its health effects on Ganga-Meghna-Brahmaputra plain. $J$. Environ. Monitor. 2(3): 12-18

Environment Agency (2004). Assessing the groundwater pollution potential of cemetery Development; Waterside Drive, Aztec, West Almondsburg, Bristol.

Ikhile, CI; Olorode, DO (2011). Impact of climate change on underground-water resources development in Benin-Owena river basin, Edo State, Nigeria: case study. European J. Sci. Res. 63 (2): $272-278$.

Ikhuoria, IA (1987). Urban land use patterns in traditional Nigeria City: A case study of Benin City. Land use policy. 4 (1): 12-16

Kiptum, CK; Ndambuki, JM (2012). Well water contamination by pit latrines: a case Study of Langas. Inter. J. Water Res. Environ. Eng. 4 (2): 35-43.

Kudesia, VP; Kudesia, R (2008). Water Pollution, K. K. Mittal, Pragati Prakashan, Educational Publishers, Meerut, India, pp 738

Kuma, A; Dua, A (2009). Water quality index for assessment of water quality of River Ravi at Madhopur (India). Global J. Environ. Sci. 8(1): 49 $-57$
Okokoyo, PA; Rim-Rukeh, A (2004). Sand bed filtration in refinery wastewater polishing. Multidisciplinary J. Empirical Res. 1: 164 - 170

Pedley, S; Guy, H (1996). The public health implications of microbiological contamination of groundwater. Quarterly J. Eng. Geol. 30: 179-188

Queensland Health Scientific Services (1996); Water Microbiology Coliform-Membrane Filtration Method, XX03, http://www.dwi.gov.uk Retrieved June 14, 2011

Rim-Rukeh, A (2009). Environmental Science: An Introduction. Kraft Books Limited, Ibadan, Nigeria, pp: 609

Rim-Rukeh, A., Ikhifa, O. G., Okokoyo, P. A., Awatefe, J.K. and Odjighere, M. O. (2008); Physicochemical characteristics of borehole water in Warri, Delta State, Nigeria; Agbor J. Sci. 3: 133 $-140$

Rodrigues, L. and Pacheco, A. (2003); Groundwater contamination from cemeteries, cases of study; Environmental 2010: Situation and Perspectives for the European Union, 6 - 10 May 2003, Porto, Portugal

Skinner, B. J. and Portar, S. C. (1995); the Blue Planet: An Introduction to Earth System Science. John Wiley and Sons, Inc. 493 